\title{
PENGUNAAN EKSTRAK TANAMAN KROKOT, KEMANGI DAN MENGKUDU ALTERNATIF PENGGANTI EEG STIMULAN PADA BURUNG PUYUH (Coturnix coturnix japonica $\mathrm{L}$ )
}

\section{(Use of Purslane, Basil and Noni Plant Extracts to Replace Stimulant Eegs In Quail (Coturnix coturnix japonica L))}

\author{
Komarudinn Adam ${ }^{1}$, Nur Sjafani ${ }^{2}$, dan M. Ade Salim ${ }^{3}$ \\ 1,2,3 Fakultas Pertanian, Universitas Khairun \\ email: \\ ${ }^{1}$ komarudinadam@gmail.com \\ ${ }^{2}$ nursjafani@ymail.com \\ 3 mades@gmail.com
}

\begin{abstract}
Abstrak
Tujuan dari penelitian ini adalah mengetahui pengaruh pengunaan ekstrak tanaman krokot, kemanggi dan mengkudu sebagai alternatif pengganti egg stimulan pada burung puyuh (Coturnikx cotunikx japonica L). Metode yang digunakan adalah Rancangan Acak Lengkap (RAL) dan dilanjutkan dengan uji LSD. Ransum dan air minum diberikan secara ad libitum. Parameter yang diamati pada penelitian ini, yaitu umur pertama bertelur, daya tetas, fertilitas dan bobot tetas. Terdiri dari perlakuan 4 perlakuan dan 3 ulangan. Masing-masing R0 = Kontrol; R1 = Campuran Ekstrak 7,5\% + air; R2 = Campuran Ekstrak 15\% + Air, R3 = Campuran Ekstrak 22,5\%+ air. Hasil dari penelitian ini memperlihatkan pemberian ekstrak tanaman krokot, kemangi dan mengkudu dalam air minum puyuh memberikan pengaruh yang signifikan $(\mathrm{P}<0,01)$ terhadap fertilitas dan daya tetas, sedangkan umur pertama bertelur dan bobot tetas memberikan pengaruh berbeda tidan nyata $(\mathrm{P}>0,01)$. Kesimpulan dari penelitian ini adalah penggunaan ektrak tanaman krokot, kemangi dan mengkudu dapat digunakan sebagai pengganti egg stimulan dalam air minum pada puyuh.
\end{abstract}

Kata Kunci : Puyuh, fertilitas,, daya tetas, bobot tetas.

\begin{abstract}
The purpose of this study was to determine the effect of using purslane, basil and noni plant extracts as an alternative to egg stimulants in quail (Coturnikx cotunikx japonica $L$ ). The method used was a completely randomized design (CRD) and continued with the LSD test. Rations and drinking water were given ad libitum. The parameters observed in this study were age at first laying eggs, hatchability, fertility and hatching weight. Consisting of 4 treatments and 3 repetitions. Respectively $R O=$ Control; $R I=$ Extract mixture $7.5 \%+$ water $; 2=$ Mixed Extract $15 \%+$ Water, $R 3=$ Mixed Extract $22.5 \%+$ water. The results of this study showed that the application of purslane, basil and noni
\end{abstract}


plant extracts in quaildrinking water had a significant effect $(P<0.01)$ on fertility and hatchability, while the age at first laying eggs and hatching weight had no significant effect $(P>0,01)$. From this research is the use of purslane plant extract, basil and noni can be used as a substitute for egg stimulants in drinking water in quails.

Keywords : Quail, fertility, hatchability, hatching weight.

\section{Pendahuluan}

Burung puyuh banyak dikenal dimasyarakat dan sudah banyak diternakkan oleh masyarakat Merupakan salah satu ternak unggas penghasil telur dengan produksi yang tingg jika dibandingkan dengan unggas lainnya. Telur yang dihasilkan antara 250-300 butir (Agromedia, 2002; Diwayani et al., 2019).

Faktor genetik dan lingkungan adalah beberapa faktor yang mempengaruhi produktivitas burung puyuh. Faktor linkungan adalah faktor yang mendukung produktivitas melalui pemberian pakan. Secara umum pakan merupakan komponen penting dalam pemeliharaan unggas. Komponen tertinggi dalam produksi pada pemeliharaan unggas adalah pakan (69-70\%). Penggunaan pakan komersil mebutuhkan biaya yang cukup tinggi. Di Kota Ternate dan secara umum Maluku Utara mendatangkan pakan dari luar daerah sehingga harga pakan menjadi lebih tinggi.

Banyak peternak menggunakan feed suplemen dalam campuran pakan dan juga air minum pada ternak puyuh yang bertujuan untuk meningkatkan produksi telur dari ternaknya (puyuh). Peternak seing menggunakkan egg stimulan sintetissebagai suplement yang dapat meningkatkan produksi telur, mempercepat waktu bertelur. Namun penggunaan feed suplement sintetis dapat menimbulkan residu.

Feed suplemen yang berasal dari tanaman herbal memiliki manfaat yang penting dan sangat baik digunakan sebagai campuran bahan pakan dan dapat diberikan melalui air minum pada ternak. Pemanfaatan tanaman herbal sepeti tanaman krokot, kemangi dan mengkudu memiliki zat aktif yang terdiri campuran senyawa bioaktif. Kandungan Omega-3 didalam tanaman krokot dapat menurunkan kadar kolesterol pada telur, kandungan minyak atsiri pada daun kemangi memiliki fungsi sebagai anti bakteri dan kandungan anti oksidan berfungsi untuk mencegah oksidasi lemak dalam daun mengkudu (Bestari et al., 2005). Berdasakan beberapa penelitian, ketiga tanaman herbal ini memiliki berfungsi untuk meningkatkan ketahanan tubuh, penyerapan nutrisi sanggat efisien bagi pertumbuhan ternak sehingga meningkatkan performa dari puyuh yaitu umur pertama bertelur, bobot telur, daya tetas dan fertilitas adalah beberapa parameter untuk menilai produktivitas dari ternak puyuh. Untuk itu dilakukan penelitian yang bertujuan untuk pengaruh pengunaan ekstrak tanaman krokot, kemanggi dan mengkudu sebagai alternatif pengganti egg stimulan pada burung puyuh (Coturnikx cotunikx japonica $\mathrm{L}$ ).

\section{Metodologi}

\subsection{Waktu dan Tempat}

Penelitian ini dilaksanakan di kandang Laboratorium Lapang Kelurahan Fitu, Fakultas Pertanian Prodi Peternakan Universitas Khairun, Ternate. Penelitian dilaksanakan bulan Maret sampai Juni 2020. 


\subsection{Objek dan Metoda Penelitian}

\section{Obyek Penelitian}

Penelitian ini menggunakan 114 ekor puyuh (DOQ). Menggunakan baterei bersekat yang berisi 12 ekor tiap ukuran kandang : $150 \mathrm{~cm}$ x 60 x $150 \mathrm{~cm}$. Menggunakan alat yaitu timbangan digital, mesin tetas. Kandungan ransum yang diberikan bahan kering $(83,71 \%)$, abu $(10,45 \%)$, protein kasar (22\%), serat kasar (9,59), lemak kasar (5,63\%), Ca (4,58\%), P (1,9\%), energi bruto (3980 $\mathrm{Kal} / \mathrm{g})$.

\section{Metode Penelitian}

Metode penelitian menggunakan metode eksperimental dengan menggunakan Rancangan Acak Lengkap (RAL), terdiri dari 4 perlakuan, 3 ulangan masing-masing ulangan terdapat 12 ekor (4 $\mathrm{x} 3 \mathrm{x}$ 12) sehingga total pengamatan 12 unit dan 144 ekor. Perlakuan yang diberikan pada air minum berupa campuran ektrak tanaman krokot, kemangi dan mengkudu. Perlakuan yang diberukan dalam air minum adalah : $\mathrm{R} 0=$ Kontrol; R1 $=$ Campuran Ekstrak 7,5\% +air; R2 = Campuran Ekstrak 15\% + Air, R3 = Campuran Ekstrak 22,5\% + air. Untuk menganalisis data dilakukan analisis sidik ragam jika terdapat rataan perlakuan berbeda di lanjutkan dengan Uji LSD.

\section{Peubah yang Diamati}

1. Umur bertelur pertama dihitung dengan mencatat saat pertama kali puyuh bertelur (hari).

2. Fertilitas : Perbandingan jumlah telur fertil dengan jumlah telur yang ditetaskan dikalikan seratus persen

3. Daya tetas : perbandingan jumlah telur yang menetas dengan telur yang fertil dikalikan seratus persen

4. Bobot tetas : Bobot tetas dipereoleh dengan menimbang bobot DOQ setelah kering bulunya dengan timbangan digital dinyatakan dalam (gram/butir).

\section{Hasil dan Pembahasan}

Rataan umur pertama bertelur, fertilitas, daya tetas dan bobot tetas puyuh dapat dilihat pada Tabel 1.

Tabel 1. Rataan umur pertama bertelur, fertilitas, daya tetas dan bobot tetas puyuh

\begin{tabular}{lcccc}
\hline \multirow{2}{*}{ Peubah } & \multicolumn{4}{c}{ Perlakuan } \\
\cline { 2 - 5 } & R0 & R1 & R2 & R3 \\
\hline Umur pertama bertelur & 45,67 & 40,67 & 42,00 & 41,33 \\
Fertilitas & $90,56^{\mathrm{a}}$ & $96,91^{\mathrm{b}}$ & $100,00^{\mathrm{a}}$ & $100,00^{\mathrm{bc}}$ \\
Daya Tetas $_{\text {Bobot Tetas }^{\text {th }}}$ & $71,56^{\mathrm{a}}$ & $83,69^{\mathrm{b}}$ & $86,98^{\mathrm{ab}}$ & $93,29^{\mathrm{c}}$ \\
\hline
\end{tabular}

Keterangan : - Angka berbeda pada baris yang sama menunjukan pengaruh berbeda sangat nyata $(\mathrm{P}<0,01) .{ }^{\text {tn }}$ menunjukan perbedaan yang tidak nyata

\section{UMUR PERTAMA BERTELUR}

Puyuh betina yang sudah mencapai dewasa kelamin ditandai dengan peneluran pertama kali bertelur dan untuk pejantan mulai mengeluarkan suara khas (Wiradimaja et al., 2007). Hasil 
analisis statitik penelitian menjunjukkan pada perlakuann R0 (kontrol) rataan umur pertama bertelur lebih panjang dibandingkan dengan puyuh yang diberikan perlakuan. Berdasarkan analisis statistik memperlihatkan pemberian campuran ekstrak tanaman krokot, kemangi dan mengkudu dalam air minum menunjukkan adanya pengaruh tidak nyata $(\mathrm{P}>0,01)$ terhadap umur pertama bertelur. Namun berdasarkan angka rataan memperlihatkan adanya perbedaan. Umur pertama bertelur kontrol lebih panjang $(\mathrm{R} 0=46,67)$ jika di bandingkan dengan perlakuan $\mathrm{R} 1, \mathrm{R} 2$ dan R3. Hasil penelitian ini memperlihatkan jika umur pertama bertelur dalam penelitian inilebih cepat jika dibandingkan dengan peneltian Irawan dkk (2017) menggunakan tomat dalam air minum puyuh, umur pertama bertelur dicapai pada hari ke-52 sampai dengan 57.

Proses fisiologi penbentukan telur dimulai dengan adanya ovulasi sel telur dari ovarium. Sebelum diovulasikan sel telur dimatangkan dalam folikel ovarium. Vitelogenian adalah senyawa yang penting dalam proses pemantangan sel telur, sebagai prekursor protein yang distimulasi oleh hormon edtradiol disintesis oleh hati untuk pematangan sel telur pada proses pematangan ova, Selanjutnya ditranportasikan menuju reseptor oosit melalui darah menuju ovarium sebagai bahan dasar proses folikulogenesis untuk menghasilkan telur sehingga vitelogenesis sangat penting dalam menentukan kualitas telur (Maryati et al., 2007; Yuwanta, 2007; Adriyanto et al., 2014). Adanya zat bioaktif yang terkandung pada tanaman krokot, kemangi dan mengkudu yang berfungsi untuk merangsang hormon estrogen yang berfungsi untuk meningkatkan metabolisme lemak bagi pembentukan yolk, mempengaruhi kareakter seksual betina (Yuwanta, 2007). Menurut Zainudin dan Syahruddin (2012) menyatakan umur pertama bertelur dipengaruhi oleh genetik puyuh yang dipelihara. Selanjutnya Wiradimaja et al. 2007 menyatakan bahwa selain faktor genetik juga dipengatuhi oleh kesehatan, manajemen, ransum, pencahayaan dan bobot badan.

\section{FERTILITAS}

Fertilitas adalah presentasi dari telur-telur yang menunjukkan adanya perkembagan embrio dari sejumlah telur yang di tetaskan. Agar telur dapat menetas menjadi anak telur harus dalam keadaan fertil yang disebut dengan telur tetas (Toana 2017; Sinabutar, 2009). Analisis statistik memperlihatkan pemberian ekstrak tanaman krokot, kemangi dan mengkudu menunjukkan pengaruh yang sangat nyata $(\mathrm{P}<0,01)$. Terdapat perbedaan pada rataan perlakuan karena peningkatan taraf pemberian ketiga ekstrak tanaman herbal tersebut. Semakin tinggi pemberian ekstrak dalam air minum memberikan pengaruh terhadap fertilitas dari burung puyuh. Rasyaf (1993) menyatakan bahwa selain protein, energy, serta vitamin dan mineral dibutuhkan untuk menghasilkan daya fertil yang baik untuk mendukung pertumbuhan dari embrio saat telur ditetaskan.

Peningkatan fertilitas pada pengunaan hebal pada masing-masing perlakuan menunujukan zat aktif pada masing-masing herbal yang saling berperan melengkapi dalam peningkatan fertilitas (Xin et al., 2008; Setyawati et al., 2014; ). Kandungan vitamin C dan pada ketiga bahan dan antioksidan yang berfungsi sebagai antioksidan yang menghalang radikal bebas sehingga mencegah kerusakan sel dan juga karoten yang terkadung menjaga mutu sperma dan sel telur. Menurut Mohiti et al., (2007) zat aktif seperti antioksidan pada tanaman hebal membantu sistensi kolegen yang penting dalam yang penting sebagai bahan dasar pembentukan serat fibroblas ovarium (tempat perkembagan folikel) tersusun atas serat-serat fibroblas. Pakan, mortalitas sperma, umur induk, waktu kawin serta persentase sel sperma yang abnormal dan mati adalah faktor-faktor yang mendukung fertilitas (King'ori, 2011). 


\section{DAYA TETAS}

Daya tetas adalah persentase dari jumlah telur yang menetas dari telur yang fertil. Semakin tinggi jumlah telur fertil dari sejumlah telur yang ditetaskan menghasilkan persentase daya tetas yang tinggi pula (Mayani, 2019). Hasil analisi statistik memperlihatkan pemberian perlakuan ekstrak tanaman krokot, kemangi dan mengkudu dalam air minum, menunjukkan adanya perberbeda sangat nyata $(\mathrm{P}<0,01)$ terhadap daya tetas puyuh. Selanjutnya hasil uji lanjut menunjukkan adanya pengaruh tehadap rataan antar perlakuan. Semakin tinggi pemberian ekstrak ketiga tanaman herbal menunjukkan pengaruh yang santa nyata.

Tingginya daya tetas dalam penelitian ini diduga karena adanya beberapa senyawa aktif yang memiliki salah satu fungsi sebagai anti bakteri, anti jamur terkandung dalam masing-masing tanaman yang digunakan sehingga dapat memperkecil perkembangan mikroba yang terdapat pada kerabang telur. Hasil penelitian dari beberapa peneliti yang menyatakan bahwa dalam tanaman krokot, kemangi dan mengkudu memiliki senyawa aktif sebagai zat anti bakteri yang dapat berfungsi sebagai desinfektan alami karena dapat menekan pertumbuhan sel bakteri bakteri dan jamur yang berkembang pada kerabang telur dan juga mesin tetas yang digunakan dalam proses penetasan dalam penelitian ini (Setyawati et al., 2014)

Menurut Setyawaty et al.,, (2014) tanaman yang mangandung senyawa-senyawa yang dapat membunuh bakteri dan anti peradagan, zat bioaktif dalam tanaman seperti saponin, tanin sterol yang bersenergi dengan zat ini bersifat antiseptik dan antibakteri yang berkhasiat mengobati beberapa penyakit sehingga dalam penilitian menunujukan bahwa dengan pemberian kosenrtrasi ekstra yang tinggi maka akan meningkatkan persentase daya tetas yang di hasilkan.

\section{BOBOT TETAS}

Bobot tetas puyuh adalah bobot dari DOQ setelah menetas saat bulu badanya telah kering dan sebelum diberi makan dan mimum. Bobot tetas dipengaruhi oleh berat telur. Semakin tua induk serta semakin besar telur yang ditetaskan, akan menghasilkan berat tetas yang akan semakin besar pula. Pakan induk, genetik akan mempengaruhi berat tetas dari unggas (Sutiyosi dan Kismiati, 2006; Fujiawati et al., 2012; Nazriah, 2014).

Analisis statistik dari bobot tetas menunjukkan. pemberian campuran ekstrak tanaman krokot, kemangi dan mengkudu memperlihatkan adanya pengaruh tidak nyata $(\mathrm{P}>0,01)$ terhadap bobot tetas Puyuh. Namun secara numerik perlakuan yang diberikan lebih tinggi bobot tetas dibandingan dengan kontrol. Rataan perlakuan penelitian ini jika dibandingkan dibandingkan dengan hasil penelitian Mayani (2019) masih lebih tinggi dimana hasil rataan 6,76 samapai 6,89 dengan memberikan mengkudu yang dicampurkan dalam air minum sampai level 30\% dalam air minum.

Tingginya bobot tetas dalam penelitian ini diduga karena adanya pengaruh perlakuan pemberian ekstrak krokot, kemangi dan mengkudu mengandung senyawa aktif seperti anti bakteri dan anti oksidan yang dapat mencegah perkembangan bateri pada kerabang maupun bateri yang ada dalam mesin tetas sehingga pertumbuhan embrio yang ada didalam telur tidak terganggu dan sel-sel dapat berkembang dengan baik sehingga pertumbuhan jaringan tubuh yang membentuk organ dengan baik sehingga DOQ yang dihasilkan memiliki bobot tetas yang tinggi (Setyowati, 2014; Mayati, 2019) 
Faktor-faktor yang mempengaruhi bera telur adalah faktor genetik, jumlah pemberian pakan, kualitas pakan dan lingkungan kandang. Jika suhu lingkungan terlalu tinggi dengan kelembaban yang rendah akan menyebabkan bobot tetas yang dihasilkan menurun karena mengalami dehidrasi selama proses penetasan (Toana, 2017; Listyowati dan Roospitasari, 2005).

\section{Kesimpulan}

Penggunaan ekstrak tanaman krokot, kemangi dan mengkudu dapat digunakan sebagai pengganti egg stimulan dalam air minum pada puyuh

\section{Daftar Pustaka}

Adriyanto, Arif R, Miftahurahman M, Rahayu Y. S, Chandra E, Fitrianingrum A, Chandra E, Fitrianingrum A, Angreini R, Pristihadi D N, Mustika A. A, Manalu W. 2014. Peningkatan Produktivitas Ayam Petelur Melalui Pemberian Ekstrak Daun Kemangi. Jurnal Veteriner, Vol. 15 No. 2 : 281-288.

Agromedia. 2002. Puyuh Si Mungil yang Penuh Potensi. Agromedia Pustaka. Jakarta.

Bestari J, Parakasi, A, Akil S. 2005. Pengaruh Pemberian Mengkudu (Morinda citrifolia Linn) yang Direndam Air Panas Terhadap Penampilan Ayam Broiler. Prosiding.

Diwayani, R. M. D, dan W. Saregat. 2012. Pengaruh pemberian pakan bebas pilih (free choice feeding) terhadap performens awal penularan burung puyuh (Conturnix conturnix japonica) Amina Agicultural Journal 1(1): 23-32

Fujiawati W. D, Sujana E, Danara S. 2012. Pengaruh Konsentrasi Asap Cair Tempurung Kelapa dan Fumigasi Telur Itik Terhadap Daya Tetas dan Kematian Embrio. Prosiding. Fakultas Peternakan Universitas Padjajaran. Bandung.

Irawan S.L, Syafwan, Wiganti S. 2017. Pengaruh Pemberian Tomat Dalam Air Minum Terhadap Pertumbuhan Puyuh (Coturnix-coturnix japonica) di Daerah Treopis. Repository Unja. https://repositoy.unja.ac.id/id/eprint/818 [diakses 2 Juni 2020].

King'ori, A. M. 2011. Review of thefactors that influence egg fertility andhatchability inPoultry. Int. J. Poult. Sci. 10: 483-492.

Listiyowati E dan Roospitasari K. 2005. Puyuh tatalaksana budidaya secara komersial. Penebar Swadaya. Jakarta.

Maryati, Fauzia RS, Rahayu T. 2007. Uji aktivitas antibakteri minyak atsiri daun kemangi (Ocimum basilicum) terhadap Staphylococcus dan Escherichia coli. Jurnal Penelitian Sains dan Teknologi. 8(1):30-38

Mayani R. 2019. Pengaruh Ekstrak Daun Mengkudu (Morinda citrifolia lignosae) Terhadap Persentase Daya Tetas dan Bobot Tetas Burung Puyuh. Skripsi. Fakultas Sains dan Teknologi Universitas Islam Negeri Alauddin. Makassar. 
Mohiti M. Hosseini S.A, Lotfollahian H, Shariatmadari F. 2007. Effect of , Vitamin E dan C Supplements on Performance and Immunune Response of Laying Hen During High Enviromental Temperature Probiotocs, Yeast. Internasional Journal of Poultry Science 6 (12): 895-900.

Nazriah. 2014. Pengaruh Lama Penyimpanan Telur Puyuh (Coturnix-coturnix japonica) terhadap Daya Tetas Dan Berat Telur. Skripsi. Fakultas Keguruan dan Ilmu Pendidikan Universitas Syah Kuala Darussalam. Banda Aceh.

Negoro A, Achmanu S.P, Muharlien. 2013. Pengaruh Penggunaan Tepung Kemangi Dalam Pakan Terhadap Produksi Ayam. J. Pengemb Petern Tropis : 32:270-277

Nurhayati, T, Sutarto M, dan P.S. Hardjosworo. 2000. Sukses Menetaskan Telur. Penebar Swadaya. Jakarta.

Raharjo, P. 2004. Aya Buras. Agromedia, Edhi sudjarwo. Unggas Lecture.ub.ac.id. [diakses 10 April 2020).

Rahayu, H.S. 2005. Kualitas telur tetas ayam kampung dengan waktu pengulangan inseminasi buatan yang berbeda. [skripsi]. Fakultas Kedokteran Hewan. Institut Pertanian Bogor: Bogor.

Rasyaf M. 1993. Memelihara Burung Puyuh. Kanisius. Yogyakarta

Setyowaty, R.F., Ismunandar, A dan Nurul, Q.A. 2014. Identifikasi Senyawa Antrakuinon Pada Daun Mengkudu (Morinda Citrifolia L) Menggunakan Kromatografi Lapis Lapis. Prosiding Seminar Nasional Hasil-Hasil Penelitian dan Pengabdian LPPM UMP. Purwokerto.

Sinabutar, M. 2009. Pengaruh frekuensi inseminasi buatan terhadap daya tetas telur itik lokal yang di inseminasi buatan dengan semen entok.[Skripsi]. Fakultas Pertanian Universitas Sumatra Utara. Medan

Sutiyosi S.R dan Kismiati S. 2006. Fertilitas, Daya Tetas dari Puyuh Hasil Persilangan. Skripsi. Fakultas Peternakan Universitas Diponegoro. Semarang.

Toana N M. 2017. Penggunaan Kunyit Dalam Air Minum Terhadap Produksi Telur. J. Agrisius $18(2): 64-70$.

Wiradimadja, R., W. G. Piliang, M. T. Suhartono dan W. Manalu. 2007. Umur dewasa kelamin puyuh jepang betina yang diberi tepung daun katuk (Sauropus androgynus, I. Merr). Animal Production. 9(2): 67-72.

Xin H.L., Xu Y.F., Yue X.Q., Hou Y.H., Li M., Ling C.Q. 2008. Analysis of chemical constituents in extract from Portulaca oleracea L. with GC-MS method (in Chinese). Pharmaceut. J. Chin. People's Liberat. Army. 24:133-6.

Yuwanta T. 2007. Telur dan Kualitas Telur. Gajah Mada Univertsity Press. Yogyakarta. 
Halaman 90 - 97

Zainuddin, S. dan Syahruddin. 2012. Pemanfaatan Tepung Keong Mas sebagai Subsitusi Tepung Ikan dalam Ransum Terhadap Performa dan Produksi Telur Puyuh. Laporan Penelitian. Fakultas Ilmu-Ilmu Petanian Universitas Negeri Gorontalo, Gorontalo.

Zamzamy, S.P, Sudjarwo E, Hasmiyati A.A. 2014. Pengaruh Penggunaan Daun Beluntas (Pluchea Indica Less) pada Pencelupan Telur Tetas Itik Mojosari Terhadap Daya Tetas dan Mortalitas Embrio. Junal Peternaka. 1 (I) 1-8. 